\title{
Karakter pengunjung dan radius layanan taman kota: studi kasus Taman Puputan Badung I Gusti Ngurah Made Agung, Denpasar
}

\author{
Naniek Kohdrata ${ }^{1 \star}$, Anak Agung Keswari Krisnandika ${ }^{1}$, Cokorda Gede Alit Semarajaya ${ }^{1}$ \\ 1Program Studi Arsitektur Pertamanan, Fakultas Pertanian, Universitas Udayana, Indonesia 80232 \\ *E-mail: naniek_kohdrata@unud.ac.id
}

\begin{abstract}
City Park Service Distance: Case Study of Puputan Badung I Gusti Ngurah Made Agung Denpasar Park. This research is a preliminary work on finding out how a park has been functioned as a public facility to a city. It is aimed to find out Lapangan Puputan Badung service distance range as one of Denpasar city parks. Moreover, it is also to find out the characteristic uses of the park by its users. This case study uses a survey research method. Sample of respondents are chosen using accidental sampling technique with questionnaire as media of data collection. Research findings are analyzed spatially and descriptively as well. Result shows that most samples live within $5 \mathrm{~km}$ range from the park. The park has been used mostly for recreation and exercises. People within productive age have been dominated the use of the park. Duration people spend in the park is between $1-2$ hours, however there is an interesting finding that $15 \%$ samples say that they spend $3-4$ hours in the park. There is also a strong tendency that people uses the park as a group, meaning they might be there with family, relatives, or friends. More than $50 \%$ of user respondents are the park frequent visitors. As conclusion, it can be stated that Lapangan Puputan Badung function the best to serve the dwellers within $5 \mathrm{~km}$ radius.
\end{abstract}

Keywords: city park, park service distance, public facility, puputan badung city park.

\section{Latar Belakang}

Salah satu permasalahan perkotaan adalah kompetisi pemanfaatan ruang. Hal ini terjadi pula di kota Denpasar. Pertambahan jumlah penduduk, baik karena kelahiran maupun urbanisasi, telah mendorong penguasaan ruang-ruang kota untuk hunian maupun fasilitas pelayanan masyarakat yang umumnya akan berkembang seiring dengan pertumbuhan penduduk kota. Luasan wilayah kota secara horisontal jelas tidak mengalami penambahan sebagaimana dinamika pertumbuhan penduduk. Penambahan ruang yang memungkinkan adalah secara vertikal. Pembangunan vertikal di Bali, terutama untuk rumah tinggal maksimal adalah tiga lantai atau 15 meter sesuai peraturan daerah yang ada (Perda Provinsi Bali Nomor 16 tahun 2009 tentang Rencana Tata Ruang Wilayah Provinsi Bali tahun 2009-2029). Kompetisi untuk memperoleh ruang menyebabkan harga tanah meningkat, selanjutnya berdampak pada batasan luas tanah yang mampu dimiliki. Tapak untuk rumah juga makin mengecil sehingga menuntut penghuni rumah berperilaku efisien dalam pengaturan ruang-ruang yang diperlukan. Fungsi sebagai tempat berteduh tentu menjadi prioritas utama sehingga menempatkan ruang untuk pekarangan pada urutan kesekian. Ruang hijau di rumah makin mengecil dan cenderung hilang. Ruang untuk keluarga berinteraksi, bersantai, dan kegiatan luar ruang lainnya menjadi hilang, padahal manusia secara alamiah masih perlu untuk berinteraksi dengan alam. Pemerintah kota dalam hal ini dapat berperan dengan menyediakan taman kota sebagai tempat berinteraksi warga dengan alam dan sekaligus bersosialisasi antar sesama warga atau diantara keluarga.

Taman kota adalah fasilitas publik yang dapat diakses oleh siapa saja untuk kegiatan rekreasi, olah raga, dan bersosialisasi secara cuma-cuma. Warga kota dapat memanfaatkan fasilitas tersebut untuk melepas Ielah setelah menjalankan rutinitas sehari-hari, berinteraksi dengan teman atau komunitasnya, bahkan yang sering dijumpai adalah adanya aktifitas ekonomi skala mikro, seperti penjual makanan-minuman dari pedagang di sekitar taman kota yang banyak dikunjungi. Taman kota merupakan salah satu bentuk Ruang Terbuka Hijau (RTH) yang tidak saja memiliki fungsi ekologis, namun juga sosial, ekonomi, dan estetika. Taman kota Puputan 
Badung I Gusti Ngurah Made Agung yang terletak di dekat patung Catur Muka sebagai landmark dan titik nol kota Denpasar merupakan taman kota yang banyak dikunjungi warga. Berbagai aktifitas warga kota dilakukan di tempat tersebut, seperti olah raga, anak-anak bermain, cengkerama, pentas seni, acara keagamaan, dan pameran.

Penelitian ini bertujuan untuk mengetahui jangkauan pelayanan taman kota I Gusti Ngurah Made Agung dan aktivitas yang dilakukan pengguna di tapak. Jangkauan pelayanan yang dimaksud adalah untuk mengetahui jarak tempuh dari tempat domisili pengguna menuju taman. Hasil penelitian mengenai jarak tempuh nantinya akan berguna sebagai salah satu faktor penentu kebutuhan ruang terbuka hijau taman kota dalam suatu luasan wilayah tertentu pada kota. Demikian juga tujuan pengguna mengunjungi taman tersebut diasumsikan dapat tercermin dari aktifitas yang dilakukan. Informasi mengenai karakter pengunjung yang didapat dari penelitian ini diharapkan dapat berkontribusi memberikan gambaran karakter pengguna taman di kota Denpasar, khususnya Taman kota I Gusti Ngurah Made Agung. Data karakter pengguna taman akan dapat dipakai untuk mendesain fasilitas suatu taman kota di kota Denpasar nantinya.

\section{Metode Penelitian}

Lokasi penelitian adalah taman kota Puputan Badung I Gusti Ngurah Made Agung yang terletak di kota Denpasar. Taman kota ini terletak di dekat landmark kota Denpasar, yaitu patung Catur Muka yang ditetapkan sebagai titik nol kota Denpasar. Peta lokasi penelitian dapat dilihat pada Gambar 1.

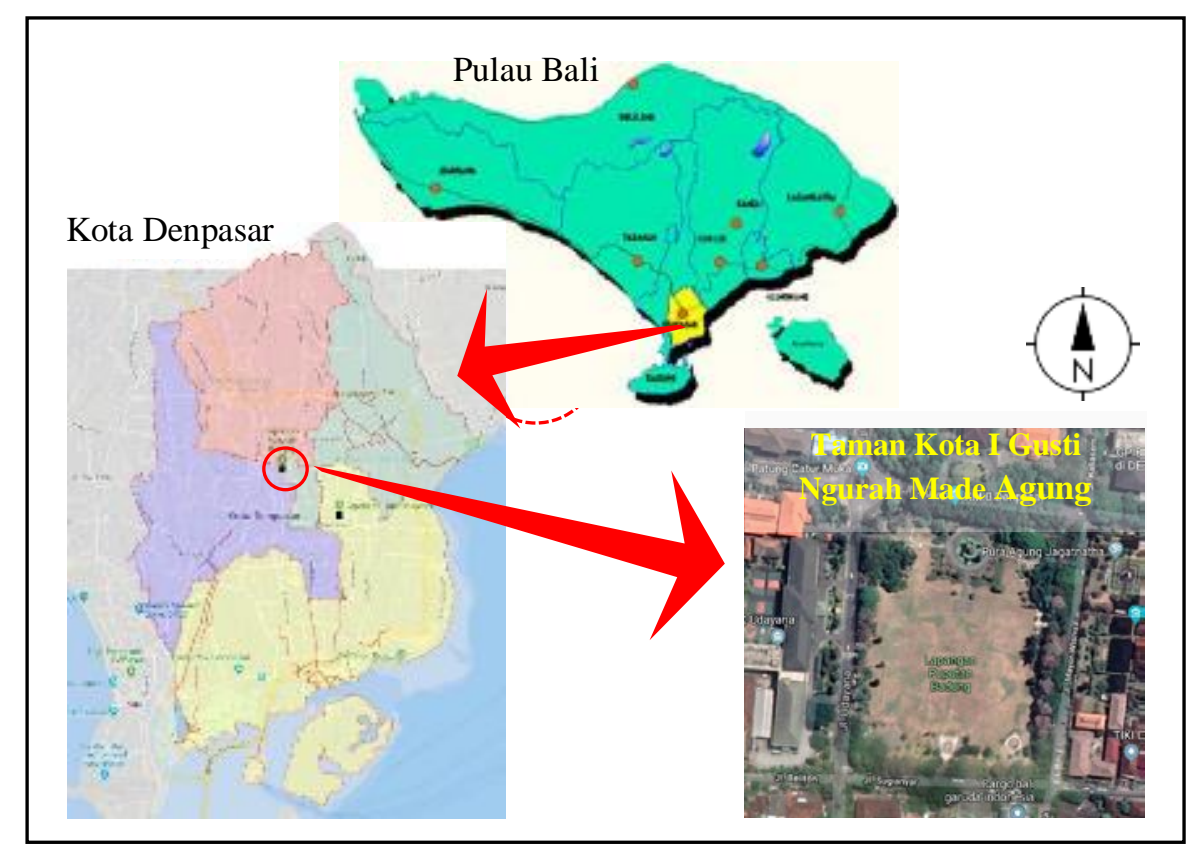

Gambar 1. Lokasi Penelitian Taman Puputan Badung - Denpasar Sumber: Diolah dari peta Pemkot Denpasar dan Google maps

Penelitian dilakukan dengan menggunakan metode survei pada pengunjung taman kota Puputan Badung. Data dikumpulkan dengan menggunakan teknik accidental sampling yang memenuhi umur minimal 15 tahun. Media informasi dan data sampel diperoleh melalui kuisioner yang ditujukan pada pengunjung taman. Data kuantitatif yang terhimpun dianalisa dan dibahas secara kualitatif untuk memperoleh gambaran deskriptif profil pengguna. Sementara data kuantitatif jarak akan dikonversikan ke dalam bentuk peta untuk analisa spasial. Analisa dengan pendekatan kualitatif dimaksudkan untuk memberi keleluasaan ruang untuk menginterpretasikan karakteristik pengguna taman yang relatif kompleks. Analisis spasial dilakukan untuk memetakan lokasi domisili responden. Perhitungan jarak relatifnya menuju ke taman kota Puputan Badung 
diukur mulai dari titik domisili responden. Pemetaan lokasi tersebut akan memperlihatkan jarak tempuh ratarata pengunjung sehingga dapat ditentukan radius pelayanan taman kota Puputan Badung.

Desain pengambilan sampel pengunjung dilakukan dengan menggunakan kriteria waktu saat mencari sampel responden. Proses pengambilan data lapang dilakukan dalam waktu dua minggu dan mengambil waktu yang diasumsikan pola penggunaan taman sedang dalam kondisi normal, yang artinya tidak sedang berlangsung acara khusus di lokasi. Kriteria kedua adalah batasan usia minimal karena pertimbangan praktis pengisian kuisioner dan perihal independensi. Faktor usia yang dipakai menjadi data minimal responden adalah berusia lebih besar sama dengan 15 tahun (15 th $=<$ ), dengan asumsi bahwa pada usia tersebut telah memiliki independensi untuk bepergian tanpa didampingi orang tua. Sampel diambil dari pengunjung pengguna di hari-hari kerja (Senin, Selasa, Rabu, Kamis, Jumat) dan pengunjung di akhir pekan (Sabtu dan Minggu). Penyebaran kuisioner dilakukan selama dua minggu. Masing-masing sampel diambil saat pagi (pukul 06:00 - 09:00), siang (pukul 11:00 - 14:00), dan sore (pukul 16:00 - 19:00). Jumlah sampel sebanyak 100 orang pengunjung dengan pembagian 50 sampel responden dari hari kerja dan 50 lainnya di akhir pekan.

\section{Hasil dan Pembahasan}

Kuisioner yang disebar kepada pengunjung sejumlah seratus pengunjung responden taman Puputan Badung dalam rentang waktu dua minggu menghasilkan 93 sampel yang sesuai kriteria responden. Sebanyak tujuh sampel yang dieliminasi karena usia responden dibawah 15 tahun. Responden sejumlah 93 orang yang berpartisipasi dalam penelitian ini terdiri dari $42 \%$ laki-laki dan $58 \%$ perempuan. Rentang umur responden pengguna Taman Puputan Badung yang mengisi kuisioner adalah $15-69$ tahun. Komposisi responden yang berpartisipasi dalam penelitian ini berdasarkan umur dapat dilihat pada Gambar 2. Komposisi pengelompokan usia pengunjung dengan mengadaptasi kriteria penduduk produktif menurut WHO (World Health Organization) menunjukkan 94\% pengunjung taman adalah dari kelompok produktif. Angka persentase tersebut dengan mengabaikan kelompok usia $<15$ tahun yang dianggap masih tergantung pada orang lain untuk bermobilitas menuju taman.

Pengunjung taman Puputan Badung sebesar 58\% ternyata berasal dari kelompok umur (Gambar 2) kurang dari 30 tahun, sementara usia pengunjung dalam rentang umur 30 - 45 tahun mengambil porsi $32 \%$. Temuan ini menunjukkan bahwa ternyata untuk kasus Taman Puputan Badung, mayoritas pengunjung adalah "anak muda", suatu istilah populer masa kita untuk mereka yang termasuk golongan remaja dan dewasa muda. Hal ini menandakan bahwa untuk usia produktif, taman kota ternyata masih merupakan salah satu obyek menarik bagi mereka. Banyaknya pengunjung usia remaja dan dewasa muda ke taman kota mmengindikasikan bahwa pilihan untuk beraktivitas di ruang ruang masih menarik bagi kategori usia tersebut.

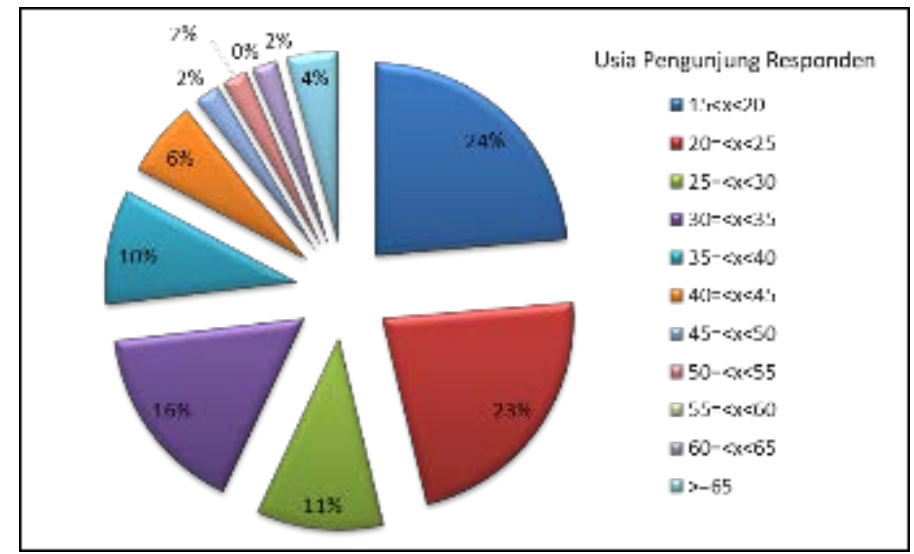

Gambar 2. Kelompok Usia Pengunjung

Sumber: Hasil pengolahan data 
Hasil jawaban responden mengenai kunjungan ke taman sebagai sebuah rutinitas atau sebaliknya menghasilkan data yang menunjukkan bahwa $52 \%$ pengguna taman melakukan kunjungan secara rutin, sementara $46 \%$ melakukan sesekali, dan hanya $2 \%$ yang merupakan pengunjung pertama kali.

Sampel pengguna taman yang memilih menjawab mengunjungi taman secara rutin adalah sebanyak 48 orang dari 93 sampel responden yang memenuhi kriteria. Dari jumlah tersebut frekwensi kunjungan rutin antara 1 - 2 kali per minggu merupakan kekerapan jumlah hari kunjungan yang terbanyak dipilih oleh pengguna taman. Sementara sebanyak $21 \%$ datang ke taman antara $3-4$ kali per minggu dan sisanya sebesar 15\% mengunjungi taman 5 kali atau lebih dalam satu minggu. Diagram kekerapan rutinitas sampel untuk kunjungan ke taman Puputan Badung dapat dilihat pada Gambar 3.

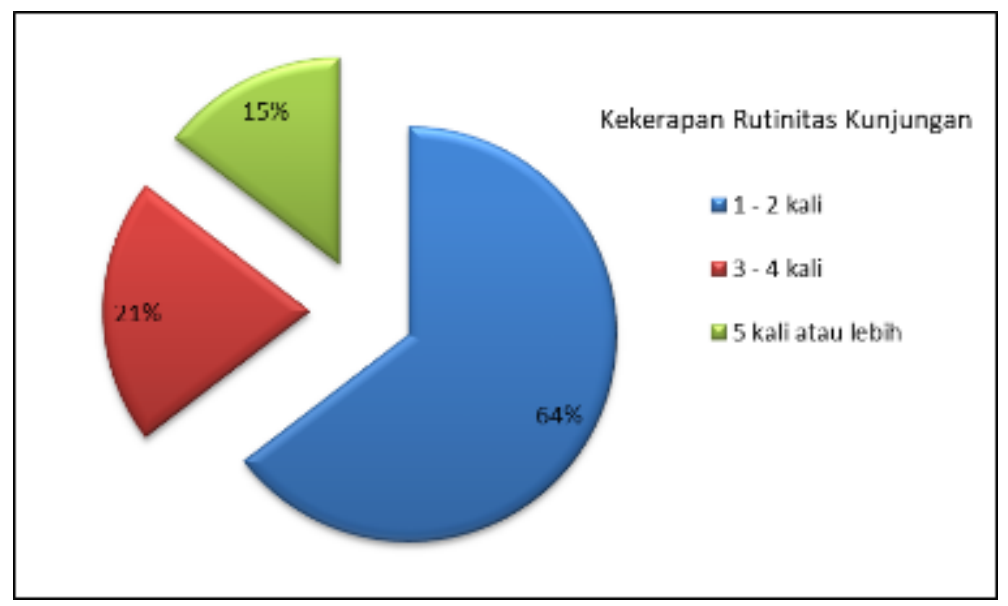

Gambar 3. Kekerapan Rutinitas Jumlah Hari Kunjungan

Sumber: Hasil pengolahan data

Sekitar setengah dari sampel reponden (52\%) merupakan pengunjung rutin dari Taman Puputan. Hal ini merupakan kondisi yang baik dilihat dari aspek tingkat ketermanfaatan taman kota sebagai ruang publik di kota Denpasar. Rutinitas kunjungan dari pengguna rutin adalah terbanyak mereka yang menggunakan antara 1 - 2 kali per minggu, disusul kemudian hampir seperempat responden memberikan indikasi bahwa taman Puputan sangat layak dikunjungi dengan fakta bahwa perminggu mereka melakukan kunjungan antara $3-4$ kali. Disamping indikasi positif ketermanfaatan taman kota, jumlah pengunjung rutin juga dapat dibaca sebagai suatu fenomena berkurangnya lahan atau ruang terbuka yang memadai untuk aktifitas ruang luar miliki pribadi. Hal ini berkesesuaian dengan yang diungkapkan Suryana (2014) dari hasil penelitiannya di kota Denpasar rmenunjukkan adanya penurunan sebanyak 13\% ruang terbuka hijau dari tahun 2003 hingga 2013. Penurunan sejumlah 13\% (setara 285 hektar) lahan tersebut dapat dipandang sebagai suatu kehilangan yang perlu diwaspadai dari aspek kualitas hidup masyarakat di suatu kota. Hal ini didukung oleh penelitian Riana, dkk (2014) yang menyatakan bahwa alih fungsi RTH di kota Denpasar sebesar 94\% terjadi karena alasan menjadi fungsi pemukiman penduduk.

Lama waktu yang dihabiskan di taman pilihan mayoritas pengunjung adalah antara satu hingga dua jam (Gambar 4). Fenomena yang cukup menarik, ternyata ada pula pengunjung yang menghabiskan waktu lebih dari dua jam di taman. Jumlah persentase tersebut mirip dengan mereka yang menghabiskan waktu kurang dari satu jam. Hal menarik lain yang perlu dicatat adalah bahwa ternyata pengunjung taman sadar atau paling tidak menganggap diri mereka sadar dengan waktu yang mereka habiskan untuk berkegiatan di taman. Terbukti dengan tidak ada seorang pun sampel responden yang memilih pilihan 'tidak tentu'. Lama waktu menghabiskan waktu untuk beraktifitas di taman kota yang ditemukan di Lapangan Puputan Badung ini juga hampir sama dengan hasil penelitian dari Nursanto (2011) di Taman Kota Menteng di Jakarta. Terdapat kemiripan jumlah kunjungan rutin pengguna taman kota antara 1 - 2 kali dalam seminggu yang berkisar 70an\% dan durasi waktu tiap kunjungan pada kisaran 50an\%. 


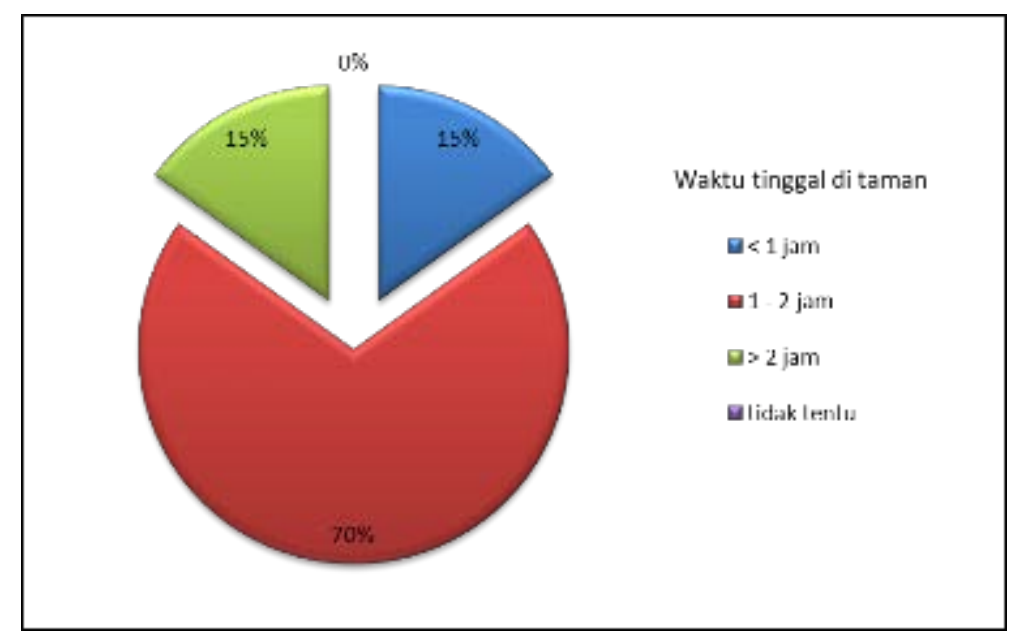

Gambar 4. Lama Waktu Tinggal di Taman

Sumber: Hasil pengolahan data

Survei terhadap pengunjung taman Puputaan Badung menunjukkan kecenderungan yang kuat bahwa dalam beraktivitas di taman kota biasa dilakukan bersama dengan orang lain (Gambar 5). Pengertian dengan orang lain dalam penelitian ini dimaknai bahwa pengunjung dalam beraktivitas di taman memiliki kecenderungan sangat kuat datang sebagai kelompok, baik dengan yang memiliki ikatan keluarga atau jenis ikatan sosial lainnya. Fenomena positif ini merupakan hal yang baik untuk kota Denpasar yang memiliki konsep kota ramah anak. Hasil penelitian Konijnendijk, et al. (2013) mengenai manfaat taman kota menunjukkan banyak indikasi keuntungan positif dari taman kota dan penggunanya. Manfaat yang diberikan oleh adanya taman kota diantaranya adalah mampu menciptakan kohesi sosial dan kondisi toleransi diantara warga pengguna. Unsur-unsur lain yang diteliti dalam riset tersebut adalah manfaat bagi kesehatan, biodiversiti, pariwisata, harga rumah sekitar taman kota, kualitas udara, dan manajemen air. Hasil yang didapat dari aspekaspek yang diteliti tersebut memperlihatkan kecendereungan positif adanya suatu taman kota di lingkungan perkotaan.

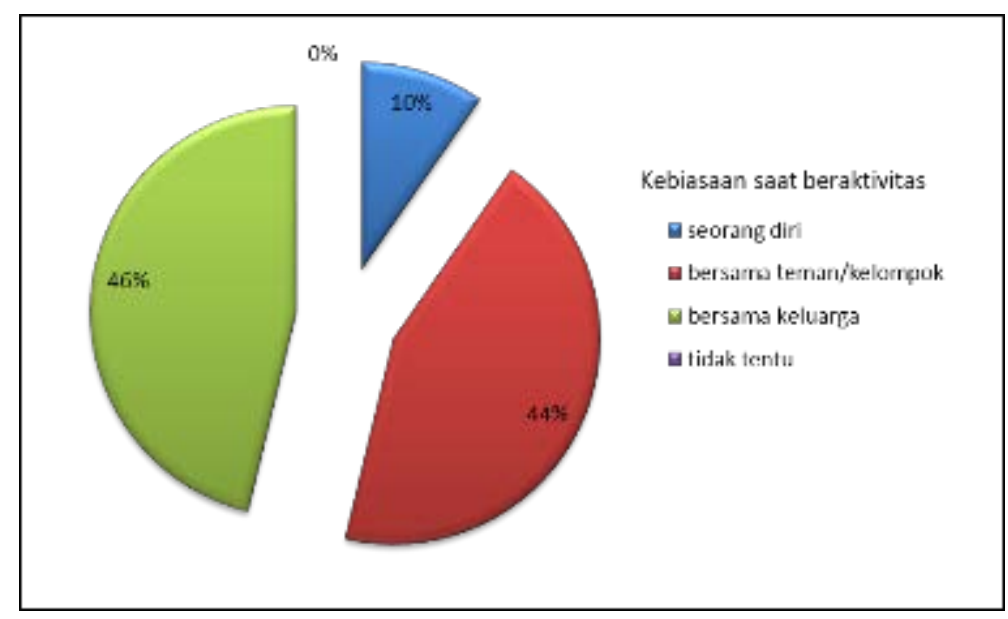

Gambar 5. Kebiasaan Sosial Individu Saat Beraktivitas Sumber: Hasil pengolahan data

Rekreasi merupakan aktifitas paling banyak dipilih oleh responden yang menjadi sampel, disusul dengan olahraga dan sosialisasi. Worpole (2007) berpendapat bahwa salah satu investasi penting pemerintah kota adalah memiliki warga yang sehat. Salah satu cara untuk memperoleh kesehatan tersebut adalah dengan 
mengajak warga untuk seseering mungkin beraktifitas di luar ruang. Aktifitas seperti olah raga, bercengkerama, dan aktifitas rekreatif lainnya dapat diwadahi oleh taman kota atau ruang publik. Sementara Travlou (2007) menegaskan pentingnya suatu taman kota sebagai wadah bagi kaum muda untuk beraktifitas dan berekspresi. Interaksi dan aktifitas postif yang terjadi antar remaja dalam lingkup taman kota merupakann bentuk dukungan bagi pertumbuhan yang sehat bagi mereka, baik secara individual maupun kelompok. Pemanfaatan Taman Kota Puputan Badung nyata bermanfaat bagi warga kota Denpasar dari aspek kesehatan secara fisik maupun psikologis. Sejalan dengan teori Travlou tentang pentingnya taman kota untuk beraktifitas bagi kaum muda, maka pengguna taman kota Puputan Badung dengan pengunjung muda sekitar 50\% (Gambar 6) diharapkan dapat memberikan kontribusi bagi pembentukan generasi muda yang sehat jiwa dan raga.

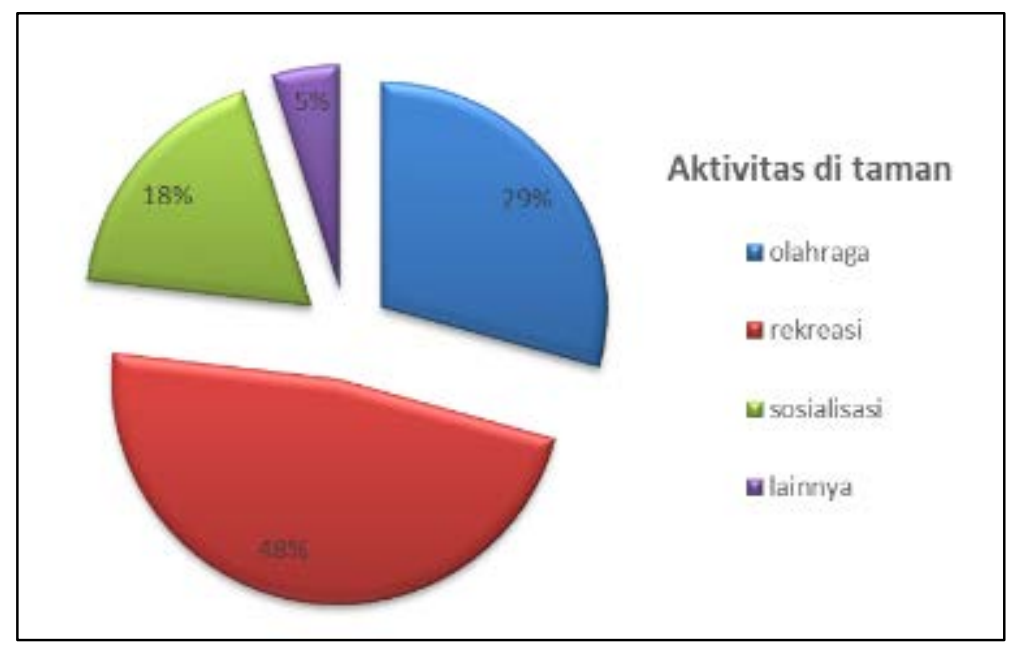

Gambar 6. Aktivitas Pengunjung

Sumber: Hasil pengolahan data

Hasil pengolahan data secara spasial memberikan gambaran bahwa sebagian terbesar pengunjung berasal dari dalam radius 5 kilometer dari lokasai taman Puputan Badung (Gambar 7). Kota domisili pengguna menunjukkan 87\% sampel responden berdomisili di dalam wilayah Kota Denpasar, 8\% wilayah Kabupaten Badung, 4\% wilayah Kabupaten Gianyar, dan 1\% lainnya. Komposisi pengunjung tersebut menunjukkan keberhasilan upaya pemerintah kota Denpasar dalam penyediaan ruang terbuka hijau yang dapat diakses publik untuk beraktifitas sebagaimana yang diamanatkan undang-undang. UU No. 26 tahun 2007 tentang Tata Ruang yang mendeskripsikan ruang terbuka hijau publik adalah RTH yang dimiliki dan dikelola oleh pemerintah daerah kota yang digunakan untuk kepentingan masyarakat umum. RTH publik yang dimaksud dalam undangundang tersebut diantara adalah taman kota, taman pemakaman umum, jalur hijau sepanjang jalan, sungai, dan pantai. Undang-undang tersebut diterjemahkan secara lebih teknis dalam Peraturan Menteri Pekerjaan Umum Nomor 5 tahun 2008 mendefinisikan taman kota sebagai sebidang lahan terbuka yang berfungsi sosial dan estetika sebagai sarana kegiatan rekrestif, edukasi atau kegiatan lain pada tingkat kota. 


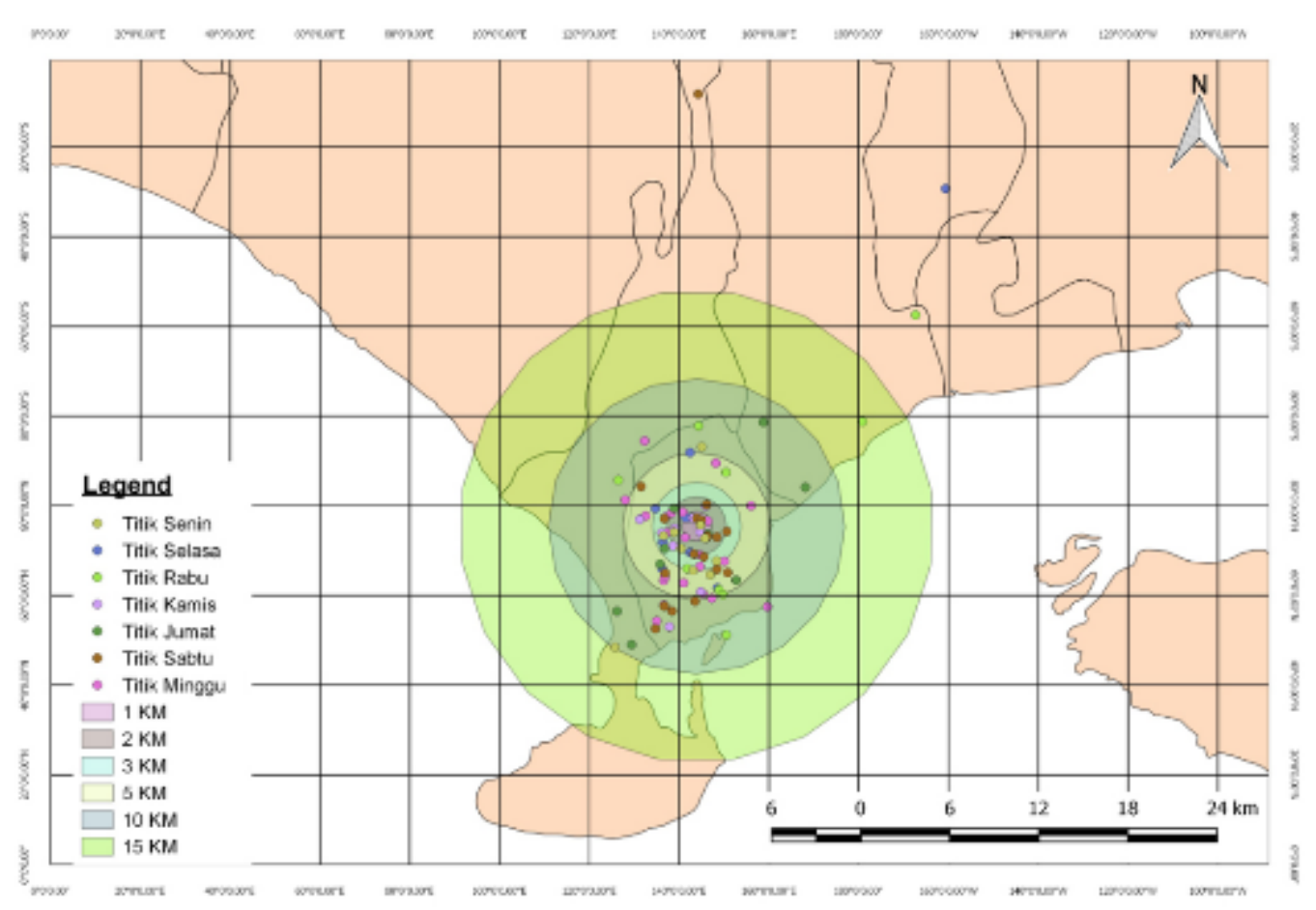

Gambar 7. Sebaran Spasial Pengguna Taman Puputan Badung Sumber: Hasil pengolahan data

Pengunjung taman kota Puputan Badung mengindikasikan bahwa taman kota tersebut merupakan tempat berkumpul. Tempat bersosialisasi masyarakat kota Denpasar salah satunya terjadi di ruang publik berupa taman kota. Hal ini sangat menarik karena tidak semua jenis taman yang memiliki fungsi ruang publik sengaja dikunjungi dan dipergunakan oleh kelompok. Yang dimaksud dengan kelompok disini adalah individuindividu yang saling mengenal dan kemudian bersepakat untuk datang bersama-sama ke taman kota dengan tujuan memanfaatkan fasilitas yang disediakan.

\section{Simpulan dan Saran}

\subsection{Simpulan}

Simpulan dari penelitian ini adalah Taman Puputan Badung menjalankan fungsinya sebagai ruang publik untuk melayani pengguna warga kota Denpasar. Radius efektifitas layanan sebagai taman kota yang bisa diakses oleh publik ada dalam selang radius $5 \mathrm{~km}$ dari lokasi tapak. Dua aktifitas utama yang menjadi alasan dominan pengguna datang ke taman kota adalah untuk rekreasi dan olah raga. Pengguna taman dalam kategori remaja dan dewasa muda mendominasi jumlah kunjungan. Taman kota Puputan Badung sebagai salah satu ruang publik terindikasi memberikan manfaat positif bagi pengunjung taman dikarenakan lebih dari setengah responden merupakan pengunjung yang rutin datang ke taman kota tesebut.

\subsection{Saran}

Penelitian ini masih bersifat eksplorasi untuk mengetahui karakter pengunjung taman, mengingat obyek penelitian ini secara spesifik untuk studi kasus Taman Puputan Badung I Gusti Ngurah Made Agung di kota Denpasar. Karakter pengunjung belum dapat sepenuhnya disebut mewakili populasi pengunjung taman Puputan Badung. Namun karakter pengguna yang terekam dalam penelitian ini kiranya telah dapat memberi gambaran tentang kondisi pengunjung secara umum untuk dilakukan penelitian selanjutnya yang lebih mendalam. 


\section{Ucapan Terima Kasih}

Penulis mengucapkan terima kasih kepada Fakultas Pertanian Universitas Udayana dan LPPM Universitas Udayana yang telah menyetujui untuk mendanai penelitian ini. Penelitian dibiayai DIPA PNBP Universitas Udayana sesuai dengan Surat Perjanjian Penugasan Pelaksanaan Penelitian, Nomor Kontrak: 1698 C /UN14.1.2.6.II/LT/2017, tanggal 4 Juli 2017.

\section{Daftar Pustaka}

Konijnendijk, C.C., M. Annerstedt, A.B. Nielsen, S. Maruthaveeran. 2013. Benefits of Urban Parks: A systematic review. A report for IFPRA, Copenhagen \& Alnarp.

Mani, N.P.A.C., G.M. Adnyana, N. Kohdrata. 2012. Studi Home Range Penggunaan Taman Kota: Studi kasus Lapangan Puputan Margarana Niti Mandala, Denpasar, Bali. E-Jurnal Agroekoteknologi Tropika, volume 1 nomor 2, Oktober 2012. Program Studi Agroekoteknologi Fakultas Pertanian Universitas Udayana.

Nursanto, Ali. 2011. Analisa Taman Menteng sebagai Taman Kota Berdasarkan Kriteria Kualitas Taman Jakarta Pusat. Jurnal Planesa, volume 2 nomor 1, Mei 2011. Hal: 10-16. Universitas Esa Unggul.

Peraturan Menteri Pekerjaan Umum Nomor 5 tahun 2008 tentang Pedoman Penyediaan dan Pemanfaatan Ruang Terbuka Hijau di Kawasan Perkotaan. Dirjen Penataan Ruang Departemen Pekerjaan Umum.

Riana, I N., Widiastuti, I.B.G. Primayatna. 2014. Kajian Alih Fungsi Ruang Terbuka Hijau di Kota Denpasar. Ruang-Space: Jurnal Lingkungan Binaan, volume 1 nomor 1, April 2014. Hal: 85-98. Program Studi Magister Arsitektur Universitas Udayana.

Suryana, I Gede Putra Eka. 2014. Analisis Ketersediaan Ruang Terbuka Hijau dan Indeks Kenyamanan (Kasus Kota Denpasar Provinsi Bali Periode Tahun 2003 dan 2013). Tesis Program Studi S-2 Geografi Fakultas Geografi Universitas Gadjah Mada (tidak dipublikasi).

Travlou, P. 2007. Mapping Youth Spaces in the public realm: identity, space and social exclusion. Dalam Open Space - People Space. C.W. Thompson and P. Travlou (editor). Taylor \& Francis e-Library.

Undang-Undang Republik Indonesia Nomor 26 tahun 2007 tentang Penataan Ruang.

Worpole, K. 2007. The Health of the People is the Highest Law: Public health, public policy, and green space. Dalam Open Space - People Space. C.W. Thompson and P. Travlou (editor). Taylor \& Francis e-Library. 